\title{
PEMBUATAN ALAT UJI PERPINDAHAN PANAS SECARA RADIASI
}

\author{
Wahyono, S.T., M.T., Ir. Ilyas Rochani, M.T., \\ Program Studi Teknik Konversi Energi, Jurusan Teknik Mesin Politeknik Negeri Semarang \\ Jl. Prof. Sudarto, S.H., Tembalang, Semarang, 50275
}

Telp. (024) 7473417, 7499585, Faks. (024) 7472396

\begin{abstract}
Abstrak
Praktikum perpindahan panas di Program Studi Teknik Konversi Energi Politeknik Negeri Semarang meliputi praktikum konduksi dan konveksi. Untuk itu perlu untuk membuat alat uji perpindahan panas radiasi yang bertujuan untuk melengkapi alat ukur perpindahan panas. Metode yang digunakan yaitu pengukuran suhu dengan alat ukur yang nilainya kemudian diolah dalam persamaan radiasi. Variabel penelitian meliputi jarak antara benda uji, sudut antara benda uji dan suhu sumber panas. Data dari pengujian alat kemudian dibuat tabel dan dibandingkan hasilnya dengan menganalisa grafik. Tahap akhir dari pengujian ini yaitu mendapatkan nilai laju perpindahan panas dengan beberapa variabel yang digunakan. Nilai laju perpindahan panas terbesar didapatkan ketika pengujian pada suhu $150^{\circ} \mathrm{C}$ sudut $0^{\circ}$ pada jarak $5 \mathrm{~cm}$ sebesar 18,5457 Watt, sedangkan nilai laju perpindahan panas terendah didapatkan ketika pengujian pada suhu $125^{\circ} \mathrm{C}$ sudut $30^{\circ}$ pada jarak $25 \mathrm{~cm}$ sebesar 1,5633 Watt.
\end{abstract}

Kata Kunci : Perpindahan Panas Radiasi, Jarak Benda Uji, Sudut Benda Uji, Suhu Sumber, Laju Perpindahan Panas

\section{PENDAHULUAN}

Dalam sistem pendidikan pada Program Studi Teknik Konversi Energi, Jurusan Teknik Mesin Politeknik Negeri Semarang, setiap mata kuliah yang diajarkan harus disertai dengan praktikum. Berdasarkan pengamatan selama mengikuti mata kuliah perpindahan panas belum ada alat praktikum perpindahan panas secara radiasi. Sedangkan untuk jenis perpindahan panas secara konduksi dan konveksi sudah ada alat yang digunakan untuk praktikum. Untuk memecahkan permasalahan diatas terdapat beberapa alternatif, diantaranya yaitu dengan membeli alat uji perpindahan panas radiasi atau dengan membuat alat uji perpindahan panas radiasi. Dari kedua alternatif tersebut terdapat kelebihan dan kekurangan masing-masing. 
Dengan membeli alat uji perpindahan panas radiasi, kelebihannya yaitu praktis dan memiliki banyak pilihan. Diantara kelebihan tersebut, kekurangan membeli alat perpindahan panas radiasi yaitu harga yang mahal. Apabila menggunakan alternatif lain yaitu dengan membuat alat uji perpindahan panas radiasi, kelebihannya yaitu dapat menyesuaikan kebutuhan pengujian, dapat menambah keterampilan mahasiswa dan biaya yang dibutuhkan lebih murah. Kelemahan apabila membuat alat uji perpindahan panas radiasi yaitu membutuhkan waktu lebih lama dalam pembuatan.

Oleh karena itu dengan mempertimbangkan kedua alternatif tersebut maka diputuskan untuk membuat tugas akhir dengan judul "Pembuatan Alat Uji Perpindahan Panas secara Radiasi". Harapan dengan adanya media pembelajaran perpindahan panas secara radiasi tersebut dapat digunakan untuk menunjang proses perkuliahan dalam rangka pengembangan mata kuliah perpindahan panas.

\section{TINJAUAN PUSTAKA}

\section{Pengertian Perpindahan Panas}

Perpindahan panas atau yang sering disebut heat transfer merupakan salah satu dari disiplin ilmu teknik thermal yang mempelajari cara menghasilkan panas, menggunakan panas, mengubah panas dan menukarkan panas di antara sistem fisik. Bila dalam suatu sistem terdapat perbedaan suhu, atau bila dua sistem yang suhunya berbeda disinggungkan, maka akan terjadi perpindahan energi yang disebut juga sebagai perpindahan panas (Kreith, 1991:1). Perpindahan panas merupakan bukti dari hukum termodinamika yang pertama tentang energi yang tidak dapat diciptakan maupun dihilangkan. Energi hanya dapat dipindahkan dan berubah dari satu bentuk ke bentuk lainnya.

Perpindahan panas selalu terjadi dari benda yang panas ke benda yang dingin. Jika beberapa benda saling berdekatan satu sama lain dan mempunyai temperatur yang berbeda kemudian benda yang panas akan menjadi dingin dan benda yang dingin menjadi panas hingga mencapai temperatur keseimbangan (Pearson 1992).

\section{Perpindahan Panas Radiasi}

Koestoer (2002: 183) menyatakan bahwa radiasi adalah proses perpindahan panas melalui gelombang elektromagnet atau paketpaket energi (photon) yang dapat dibawa sampai jarak yang sangat jauh tanpa memerlukan interaksi dengan medium. Radiasi dalam perpindahan panas (thermal radiation) hanya salah satu bentuk dari jenis radiasi elektromagnetik. Perpindahan panas radiasi berpindah dengan cara pancaran melalui gelombang elektromagnet.

Panas matahari yang sampai ke bumi merupakan salah satu contoh bentuk nyata perpindahan panas secara radiasi. Meskipun jarak antara matahari dan bumi sangat jauh serta dipisahkan oleh ruang hampa, panas matahari tetap dapat sampai ke bumi melalui pancaran.

Proses radiasi adalah fenomena permukaan. Proses radiasi tidak terjadi pada bagian dalam bahan. Tetapi suatu bahan apabila menerima sinar, maka banyak hal yang boleh terjadi. Energi ka1or yang menimpa suatu permukaan, sebagian akan dipantulkan, sebagian akan diserap ke da1am bahan, dan sebagian akan menembus bahan dan terus ke luar. Jadi da1am mempelajari perpindahan panas radiasi akan dilibatkan suatu fisik permukaan (Masyitah \& Haryanto 2006).

Laju perpindahan panas radiasi suatu benda dipengaruhi oleh beberapa hal. Koestoer (2002: 184) menjelaskan bahwa laju energi yang dipindahkan tergantung kepada beberapa faktor yaitu temperatur permukaan yang mengemisi dam menerima radiasi, emisivitas permukaan yang teradiasi, refleksi, absorpsi dan transmisi, serta faktor pandang (view's factor) antara permukaan yang mengemisi dan yang menerima radiasi. Salah satu hal yang berpengaruh terhadap laju perpindahan panas secara radiasi adalah kondisi permukaan benda yang memancarkan dan menerima radiasi. Hal ini disebabkan karena sifat-sifat permukaan benda berpengaruh langsung terhadap emisivitas (daya pancar) benda tersebut. dengan kata lain, kekasaran permukaan, pelapisan serta perlakuan permukaan terhadap suatu benda akan berpengaruh terhadap proses laju perpindahan panas yang terjadi antara dua benda yang bertukar panas.

Untuk mengetahui laju perpindahan panas secara radiasi dari benda 1 ke benda 2 , dapat digunakan rumus perhitungan laju perpindahan panas seperti berikut ini:

$\mathrm{Q}=\sigma \varepsilon \mathrm{A}_{1} F_{1 \rightarrow 2}\left(\mathrm{~T}_{1}^{4}-\mathrm{T}_{2}^{4}\right)$

Dimana:

$\mathrm{Q}=$ laju perpindahan panas 
$\sigma=$ konstanta boltzman

$$
\left(5,669 \times 10^{-8} \mathrm{~W} / \mathrm{m}^{2} \mathrm{~K}^{4}\right)
$$

$\varepsilon=$ emisivitas permukaan benda

$\mathrm{A}_{1}=$ luas permukaan benda 1

$\left(\mathrm{m}^{2}\right)$

$\mathrm{T}_{1}=$ suhu benda 1

$\mathrm{T}_{2}=$ suhu benda 2

Laju energi yang dipindahkan tergantung kepada beberapa faktor:

1) Temperatur (permukaan yang memancar dan yang menerima radiasi).

2) Emisivitas (permukaan yang teradiasi)

3) Refleksi, absorpsi, dan transmisi.

4) Faktor pandang antara permukaan yang mengemisi dan yang menerima radiasi (sudut pandang antara manusia terhadap sumber radiasi). Gambar 1 menunjukkan pengelompokkan gelombang- gelombang elektromagnet.

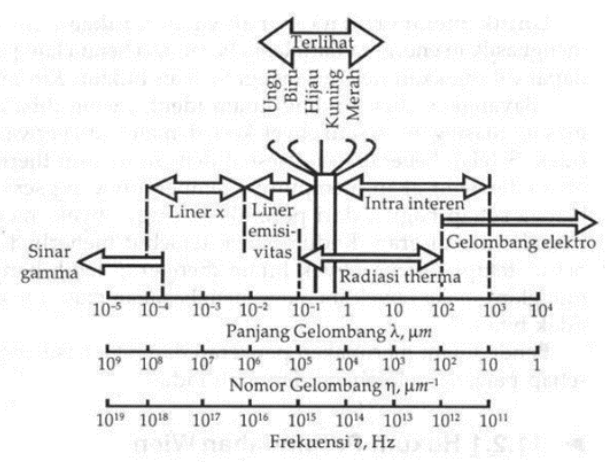

Gambar 1 Spektrum gelombang elektromagnet

Faktor Bentuk untuk Geometri Panjang Tak Hingga Arah Tegak Lurus Bidang Kertas Dua Dimensi

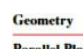
Relation
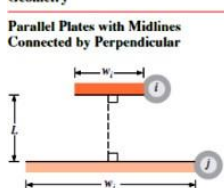

$F_{i j}=\frac{\left[\left(W_{i}+W_{j}\right)^{2}+4\right]^{1 n}-\left[\left(W_{i}-W_{j}\right)^{2}+4\right]^{1 / 2}}{2 W_{i}}$

Inclined Parallel Plates of Equal
Width and a Common Edge

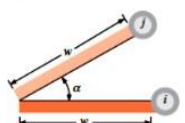

$F_{i j}=1-\sin \left(\frac{\alpha}{2}\right)$
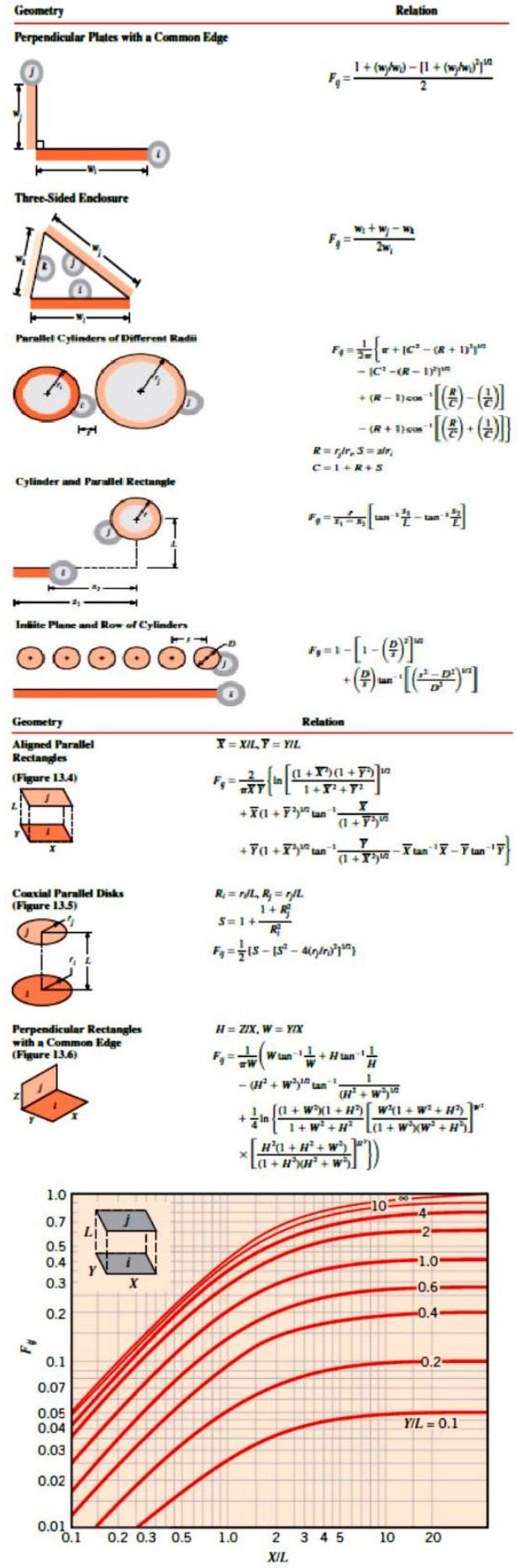

Gambar 2. Grafik faktor bentuk antara dua bidang persegi sejajar dengan ukuran yang sama 


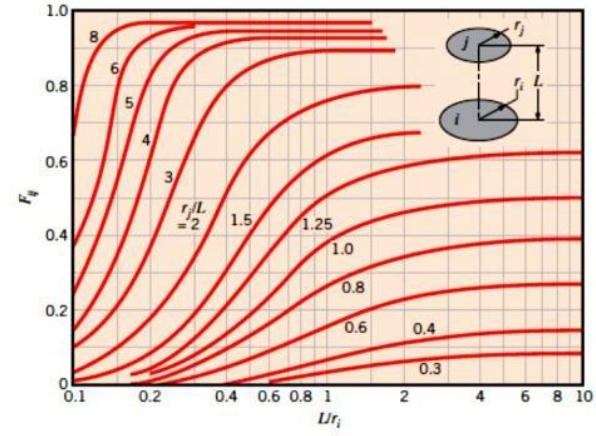

Gambar 3. Grafik faktor bentuk antara dua piringan sejajar

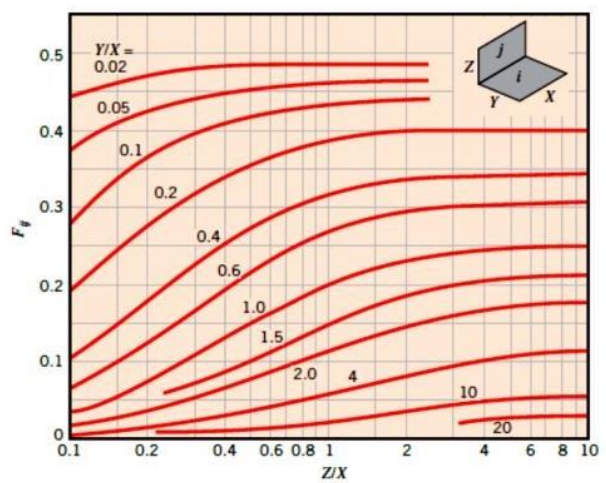

Gambar 4. Grafik faktor bentuk antara dua bidang persegi saling tegak lurus

Faktor Bentuk menggunakan Metode Cross String

Geometri seperti saluran dan saluran yang sangat panjang dalam satu arah dapat dianggap dua dimensi (karena radiasi melalui permukaan akhir dapat diabaikan). Faktor tampilan antara permukaan mereka dapat ditentukan dengan metode cross-string yang dikembangkan oleh $\mathrm{H}$. C. Hottel, sebagai berikut:

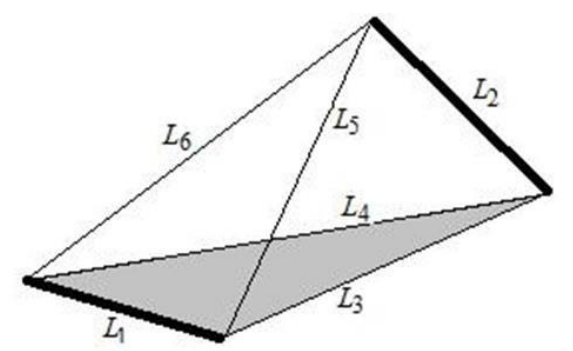

Gambar 5. Metode crossed string

\section{Faktor Bentuk dengan Obyek 2 Dimensi}

Pada kasus tertentu dijumpai kondisi pada benda 2 dimensi yang membentuk sudut $\beta$ dengan jarak $r$ dan dengan luasan $A_{1}$ dan $A_{2}$. Maka faktor bentuknya dapat dicari dengan menggunakan persamaan berikut ini. Pada gambar (a) merupakan faktor pandang dalam sketsa 3 dimensi. Gambar (b) merupakan dalam sketsa 2 dimensi.

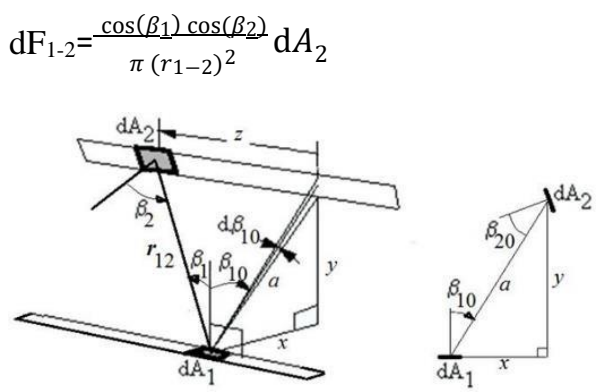

Gambar 6 (a) Sketsa 3 dimensi (b) tampilan 2 dimensi

\section{METODE PELAKSANAAN}

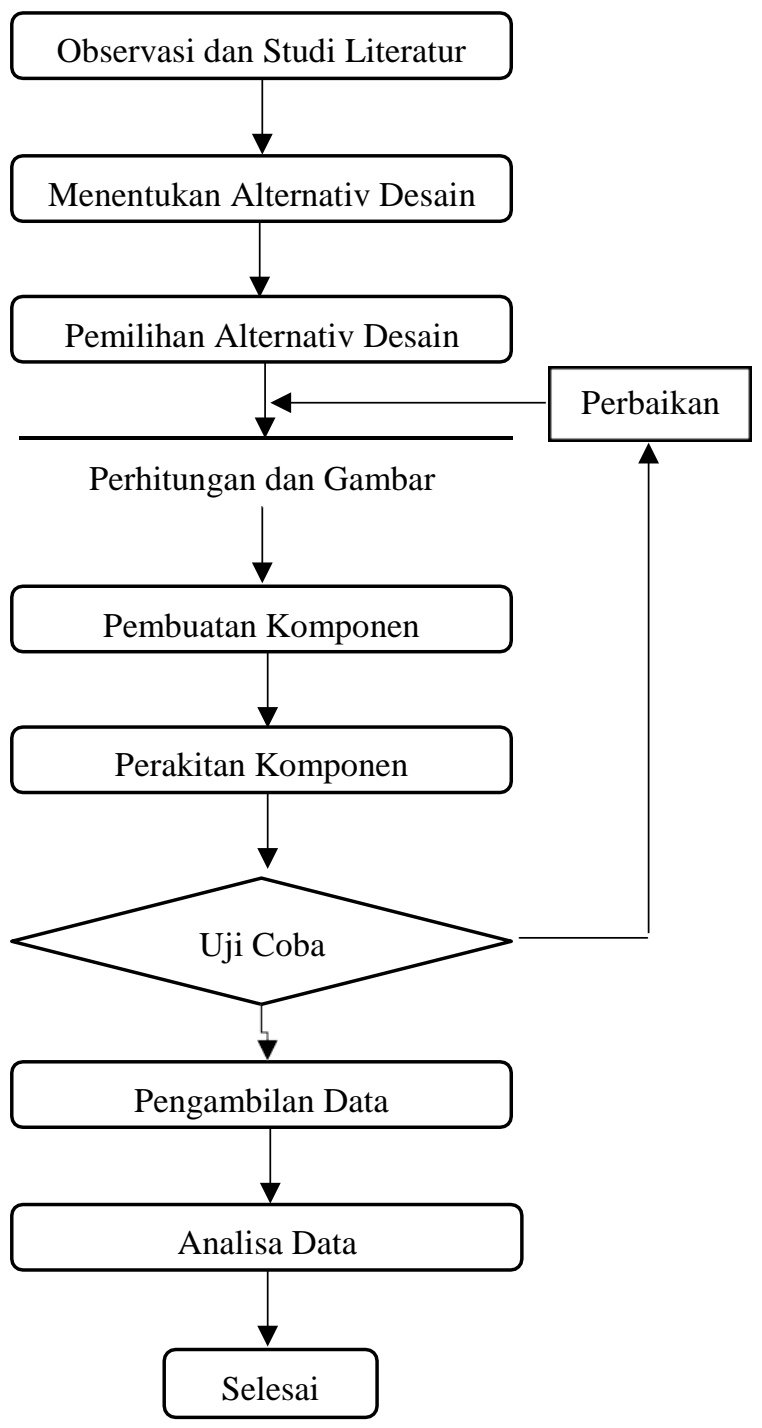

Gambar 7. Metodologi 
1. Observasi dan Study Literatur

Pengamatan atau observasi adalah aktivitas yang dilakukan makhluk cerdas, terhadap suatu proses atau objek dengan maksud merasakan dan kemudian memahami pengetahuan dari sebuah fenomena berdasarkan pengetahuan dan gagasan yang sudah diketahui sebelumnya, untuk mendapatkan informasi-informasi yang dibutuhkan untuk melanjutkan suatu penelitian. Ilmu pengetahuan biologi dan astronomi mempunyai dasar sejarah dalam pengamatan oleh amatir. Di dalam penelitian, observasi dapat dilakukan dengan tes, kuesioner, rekaman gambar dan rekaman suara.

Studi literatur adalah mencari referensi teori yang relevan dengan kasus atau permasalahan yang ditemukan.

2. Menentukan Alternatif Design

Menentukan alternatif design adalah menentukan/memutuskan pilihan lain seniterapan, arsitektur, dan berbagai pencapaian kreatif lainnya yang pada umumnya memperhitungkan aspek fungsi, estetika, dan berbagai macam aspek lainnya dengan sumber data yang didapatkan dari riset, pemikiran, brainstorming, maupun dari desain yang sudah ada sebelumnya.

3. Pemilihan Alternatif Design

Pemilihan alternatif design adalah melakukan pemilihan/penentuan terhadap seni terapan, arsitektur, dan berbagai pencapaian kreatif lainnya yang pada umumnya memperhitungkan aspek fungsi, estetika, dan berbagai macam aspek lainnya dengan sumber data yang didapatkan dari riset, pemikiran, brainstorming, maupun dari desain yang sudah ada sebelumnya.

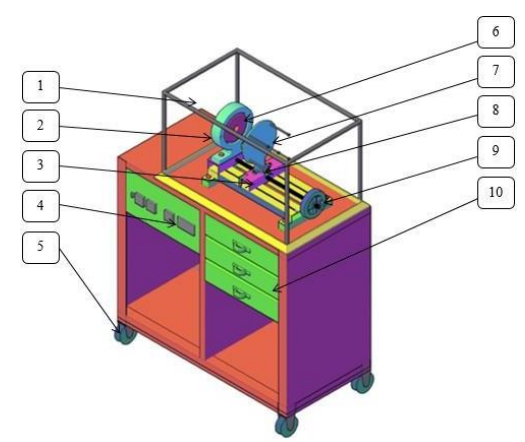

Gambar 8. Desain Alat

Keterangan :

1. Box kaca pemusat panas

2. Dudukan benda uji pemberi panas

3. Track rel untuk pengaturan jarak benda uji
4. Alat ukur untuk pembacaan suhu

5. Roda meja

6. Heater

7. Dudukan benda uji penerima panas

8. Busur pengatur sudut benda uji penerima panas

9. Pemutar ulir pengatur jarak antar benda uji

10. Laci penyimpan peralatan praktikum dan benda uji

4. Penghitungan \& Gambar

Penghitungan adalah adalah proses yang disengaja untuk mengubah satu masukan atau lebih ke dalam hasil tertentu, dengan sejumlah peubah. Gambar adalah kombinasi antara titik, garis, bidang, dan warna untuk menciptakan suatu imitasi dari suatu objek-biasanya objek fisik atau manusia.

5. Pembuatan Komponen

Pembuatan komponen adalah proses yang menghasilkan suatu komponen yaitu part-part (bagian-bagian) dari suatu produk.

6. Assembling Komponen

Assembling komponen adalah proses penggabungan/penyatuan komponen-komponen menjadi satu kesatuan yang utuh.

7. Uji Coba

Uji coba adalah proses pengujian sesuatu sebelum dipakai atau dilaksanakan seperti bahan tes, kendaraan, dan lain-lain.

8. Modifikasi

Modifikasi adalah proses melakukan beberapa perubahan yang dimaksudkan untuk menambah nilai dari suatu produk.

9. Pengambilan Data

Pengambilan data adalah teknik atau cara yang dilakukan oleh peneliti untuk mengumpulkan data. Pengumpulan data dilakukan untuk memperoleh informasi yang dibutuhkan dalam rangka mencapai tujuan penelitian. Sementara itu instrumen pengumpulan data merupakan alat yang digunakan untuk mengumpulkan data. Karena berupa alat, maka instrumen pengumpulan data dapat berupa check list, kuesioner, pedoman wawancara, hingga kamera untuk foto atau untuk merekam gambar.

10. Analisa Data

Analisa data adalah Kegiatan mengubah data hasil penelitian menjadi informasi yang dapat digunakan untuk mengambil kesimpulan dalam suatu penelitian. Adapun cara mengambil kesimpulan bisa dengan hipotesis maupun dengan estimasi hasil. 


\section{HASIL DAN PEMBAHASAN Langkah-Langkah Pengujian}

Langkah-langkah pengujian yang dilakukan yaitu :

1. Mempersiapkan alat dan bahan yang akan digunakan.

2. Membuat tabel data pengujian perpindahan panas secara radiasi dengan variasi jarak, sudut, suhu benda uji.

3. Menghubungkan alat uji dengan listrik 220V.

4. Meng-ON kan saklar pada panel kontrol.

5. Membuka penutup kaca benda uji.

6. Mengatur suhu pemberi panas dengan cara menekan tombol pada Thermo Controller.

7. Menunggu beberapa menit hingga suhu pemberi panas mencapai suhu yang diinginkan.

8. Memasang benda uji dengan cara menjepit dengan menggunakan klem dan memastikan masing-masing probe menyentuh benda uji.

9. Memasang kembali penutup kaca pada alat uji.

10. Mencatat suhu pemberi dan penerima panas sebanyak 5 kali masing-masing 3 menit.

11. Mengganti benda uji dengan benda uji yang lain setelah selesai dengan cara melepas penutup kaca kemudian melepas klem penjepit benda uji dan menggantinya dengan benda uji yang lain.

12. Mengulangi langkah percobaan 8 sampai 11 untuk variasi bahan benda uji, sudut, jarak, suhu dan bentuk benda uji, kemudian mencatat hasilnya kedalam tabel.

13. Melepas penutup kaca dan melepas benda uji setelah selesai pengujian.

14. Meng-OFF kan saklar pada panel kontrol.

15. Mencabut kabel pada sumber listrik $220 \mathrm{~V}$.

16. Menutup kembali penutup kaca benda uji.

Merapikan peralatan dan mengembalikan ke tempat semula setelah selesai melakukan pengujian.

\section{DATA HASIL PENGUJIAN}

Dari hasil pengujian alat uji perpindahan panas secara radiasi didapatkan data sebagai berikut : Tabel 1. Contoh data pengujian perpindahan panas secara radiasi dengan permukaan benda uji berwarna hitam dari bahan aluminium, stainless steel dan besi berbentuk lingkaran pada jarak pengujian $5 \mathrm{~cm}$ sudut $0^{0}$ serta pada sumber panas $125^{\circ} \mathrm{C}$

ALUMINIUM
\begin{tabular}{|l|l|l|l|l|l|l|l|}
\hline $\begin{array}{l}\text { Waktu } \\
\text { (menit) }\end{array}$ & $\begin{array}{l}\text { T1 } \\
(\mathbf{C})\end{array}$ & $\begin{array}{l}\text { T2 } \\
(\mathbf{C})\end{array}$ & $\begin{array}{l}\text { T3 } \\
(\mathbf{C})\end{array}$ & $\begin{array}{l}\text { T4 } \\
(\mathbf{C})\end{array}$ & $\begin{array}{l}\text { T5 } \\
(\mathbf{C})\end{array}$ & $\begin{array}{l}\text { T rata- } \\
\text { rata } \\
(\mathbf{C})\end{array}$ & $\begin{array}{l}\text { Emi } \\
\text { sivit } \\
\text { as }\end{array}$ \\
\hline 0 & 30 & 31 & 29,7 & 31 & 33,5 & 31,04 & 1 \\
\hline 3 & 33,2 & 33,9 & 32,5 & 33,6 & 35,9 & 33,82 & 1 \\
\hline 6 & 35,4 & 35,9 & 34,3 & 35,5 & 37,5 & 35,72 & 1 \\
\hline 9 & 37,2 & 37,7 & 35,8 & 37,1 & 38,9 & 37,34 & 1 \\
\hline 12 & 38,7 & 39,2 & 37,2 & 38,5 & 40,1 & 38,74 & 1 \\
\hline
\end{tabular}

BESI
\begin{tabular}{|l|l|l|l|l|l|l|l|}
\hline $\begin{array}{l}\text { Waktu } \\
\text { (menit) }\end{array}$ & $\begin{array}{l}\text { T1 } \\
(\mathbf{C})\end{array}$ & $\begin{array}{l}\text { T2 } \\
(\mathbf{C})\end{array}$ & $\begin{array}{l}\text { T3 } \\
(\mathbf{C})\end{array}$ & $\begin{array}{l}\text { T4 } \\
(\mathbf{C})\end{array}$ & $\begin{array}{l}\text { T5 } \\
(\mathbf{C})\end{array}$ & $\begin{array}{l}\text { T rata- } \\
\text { rata } \\
(\mathbf{C})\end{array}$ & $\begin{array}{l}\text { Emi } \\
\text { sivit } \\
\text { as }\end{array}$ \\
\hline 0 & 30 & 30,4 & 29,6 & 30,7 & 33,7 & 30,088 & 1 \\
\hline 3 & 32,8 & 33,2 & 32 & 33,2 & 35,6 & 33,36 & 1 \\
\hline 6 & 34,7 & 35,1 & 33,6 & 35 & 37,1 & 35,1 & 1 \\
\hline 9 & 36,5 & 37 & 35,2 & 36,6 & 38,4 & 36,74 & 1 \\
\hline 12 & 38 & 38,5 & 36,6 & 38 & 39,7 & 38,16 & 1 \\
\hline
\end{tabular}

\section{STAINLESS}

STEEL

\begin{tabular}{|l|l|l|l|l|l|l|l|}
\hline $\begin{array}{l}\text { Waktu } \\
\text { (menit) }\end{array}$ & $\begin{array}{l}\text { T1 } \\
(\mathbf{C})\end{array}$ & $\begin{array}{l}\text { T2 } \\
(\mathbf{C})\end{array}$ & $\begin{array}{l}\text { T3 } \\
(\mathbf{C})\end{array}$ & $\begin{array}{l}\text { T4 } \\
\text { (C) }\end{array}$ & $\begin{array}{l}\text { T5 } \\
\text { (C) }\end{array}$ & $\begin{array}{l}\text { T rata- } \\
\text { rata } \\
\text { (C) }\end{array}$ & $\begin{array}{l}\text { Emi } \\
\text { sivit } \\
\text { as }\end{array}$ \\
\hline 0 & 30 & 30,5 & 29,3 & 30,7 & 33,5 & 30,08 & 1 \\
\hline 3 & 32,9 & 33,3 & 31,7 & 33,2 & 35,4 & 33,3 & 1 \\
\hline 6 & 35 & 35,4 & 33,5 & 35,2 & 37 & 35,22 & 1 \\
\hline 9 & 36,9 & 37,2 & 35,1 & 36,8 & 38,4 & 36,88 & 1 \\
\hline 12 & 38,4 & 38,7 & 36,4 & 38,2 & 39,5 & 38,24 & 1 \\
\hline
\end{tabular}

\section{Perhitungan Data Hasil Pengujian} Perpindahan Panas secara Radiasi pada Sumber Panas $125^{\circ} \mathrm{C}$

Pertama yang perlu dicari adalah faktor bentuknya, karena faktor bentuk disini memiliki peranan yang cukup penting dalam menentukan nilai laju perpindahan panas (Q). Untuk benda uji berbentuk lingkaran dalam menentukan nilai faktor bentuknya, digunakan grafik faktor bentuk antara dua piringan sejajar. Dalam menentukan nilai faktor bentuk diperlukan data berupa nilai jari-jari (R) dari kedua lingkaran dan jarak antara kedua lingkaran (L).

Data nilai jari-jari dari kedua lingkaran adalah sebagai berikut :

$\begin{array}{lll}\mathrm{Rb} & : 8,5 \mathrm{~cm} & (0,085 \mathrm{~m}) \\ \mathrm{Rk} & : 2 \mathrm{~cm} & (0,02 \mathrm{~m}) \\ \mathrm{R} 2 & : 10 \mathrm{~cm} & (0,1 \mathrm{~m})\end{array}$


Untuk perhitungan luas permukaan lingkaran R1 adalah sebagai berikut :

$$
\begin{array}{ll}
\mathrm{Ab} & =\pi \mathrm{Rb} 2 \\
\mathrm{Ab} & =3,14 .(0,085) 2 \\
\mathrm{Ab} & =0,02268 \mathrm{~m} 2 \\
\mathrm{Ak} & =\pi \mathrm{Rk} 2 \\
\mathrm{Ak} & =3,14 .(0,02) 2 \\
\mathrm{Ak} & =0,00125 \mathrm{~m} 2
\end{array}
$$

Karena pada lingkaran pemberi panas terdapat lingkaran di tengahnya, maka luasannya menjadi

$$
\begin{aligned}
& \text { A1 }: \mathrm{Ab}-\mathrm{Ak} \\
& \text { : 0,02268 - 0,00125 } \\
& \text { : 0,02143 m2 }
\end{aligned}
$$

Nilai faktor bentuknya dijabarkan dalam perhitungan dibawah ini:

Jarak $5 \mathrm{~cm}$ :

$\mathrm{L} / \mathrm{R} 1=5 / 8,5=0,58$

$\mathrm{R} 2 / \mathrm{L}=10 / 5=2$

Maka berdasarkan grafik faktor bentuk antara dua piringan sejajar, nilai F1 $\rightarrow 2$ nya adalah $\mathbf{0 , 6 7}$.

\begin{tabular}{|c|c|c|}
\hline & & \\
\hline $\mathrm{T}$ sumber $\left(\mathrm{T}_{1}\right)$ & $=125^{0} \mathrm{C}$ & $\left(398^{0} \mathrm{~K}\right)$ \\
\hline $\mathrm{T}$ rata-rata $\left(\mathrm{T}_{2}\right)$ & $=39,52{ }^{0} \mathrm{C}$ & $\left(312,52^{0} \mathrm{~K}\right)$ \\
\hline Nilai $F_{1 \rightarrow 2}$ & $=0,67$ & \\
\hline Emisivitas & $=1$ & \\
\hline
\end{tabular}

Setelah mengetahui nilai faktor bentuk, langkah selanjutnya adalah mencari nilai laju perpindahan panas. Berikut ini contoh perhitungan yang diambil dari data percobaan ketiga bahan benda uji berbentuk lingkaran dengan permukaan berwarna hitam pada menit ke 12 :

\section{Aluminium}

Konstanta Stefan - Boltzman $=5,669 \times 10^{-8}$

$\mathrm{W} / \mathrm{m}^{2} \mathrm{~K}^{4}$

Luas Permukaan $=0,02143 \mathrm{~m}^{2}$

Menghitung nilai laju perpindahan panas secara radiasi $(\mathrm{Q})$ :

$$
\begin{aligned}
& \mathrm{Q}=\sigma \mathrm{A}_{1} F_{1 \rightarrow 2}\left(\mathrm{~T}_{1}^{4}-\mathrm{T}_{2}^{4}\right) \\
& \mathrm{Q}=5,669 \times 10^{-8} \cdot 0,02143 \cdot 0,67 \cdot\left(398^{4}-\right. \\
& \left.312,52^{4}\right) \\
& \mathbf{Q}=\mathbf{1 2 , 6 6 1 ~ W a t t}
\end{aligned}
$$

\begin{tabular}{|c|c|c|c|c|}
\hline $\begin{array}{l}\text { Waktu } \\
\text { (menit) }\end{array}$ & $\Delta \mathrm{T}(\mathrm{K})$ & $\begin{array}{l}\text { Faktor } \\
\text { Bentuk }\end{array}$ & $\begin{array}{l}\text { Luas } \\
\text { Permukaan }\end{array}$ & $\mathbf{Q}(\mathbf{W})$ \\
\hline 0 & 16564587520 & 0,67 & 0,02143 & 13,485301 \\
\hline 3 & 16282794084 & 0,67 & 0,02143 & 13,255892 \\
\hline 6 & 16080955782 & 0,67 & 0,02143 & 13,091575 \\
\hline 9 & 15887560900 & 0,67 & 0,02143 & 12,934131 \\
\hline 12 & 15717609166 & 0,67 & 0,02143 & 12,795773 \\
\hline & & & & 13,112534 \\
\hline
\end{tabular}

Dengan cara yang sama maka perhitungan

\begin{tabular}{|c|c|c|c|c|}
\hline $\begin{array}{l}\text { Waktu } \\
\text { (menit) }\end{array}$ & $\Delta \mathrm{T}(\mathrm{K})$ & $\begin{array}{l}\text { Faktor } \\
\text { Bentuk } \\
\end{array}$ & $\begin{array}{l}\text { Luas } \\
\text { Permukaan }\end{array}$ & $\mathbf{Q}(\mathbf{W})$ \\
\hline 0 & 16573563561 & 0,67 & 0,02143 & 13,492609 \\
\hline 3 & 16289692984 & 0,67 & 0,02143 & 13,261509 \\
\hline 6 & 16066909220 & 0,67 & 0,02143 & 13,080139 \\
\hline 9 & 15870908595 & 0,67 & 0,02143 & 12,920574 \\
\hline 12 & 15707964909 & 0,67 & 0,02143 & 12,787921 \\
\hline & & & & 13,108551 \\
\hline
\end{tabular}
tersebut digunakan untuk menghitung nilai laju perpindahan panas pada semua data percobaan.

Tabel 2 merupakan data perhitungan perpindahan panas secara radiasi dengan permukaan benda uji berwarna hitam dari bahan aluminium, stainless steel dan besi berbentuk lingkaran pada jarak pengujian $5 \mathrm{~cm}$ sudut $0^{0}$ serta pada sumber panas $125^{\circ} \mathrm{C}$.

ALUMINIUM
\begin{tabular}{|l|l|l|l|l|}
\hline $\begin{array}{l}\text { Waktu } \\
\text { (menit) }\end{array}$ & $\Delta \mathrm{T}(\mathrm{K})$ & $\begin{array}{l}\text { Faktor } \\
\text { Bentuk }\end{array}$ & $\begin{array}{l}\text { Luas } \\
\text { Permukaan }\end{array}$ & $\mathbf{Q}(\mathbf{W})$ \\
\hline 0 & 16546614158 & 0,67 & 0,02143 & 13,470669 \\
\hline 3 & 16229767699 & 0,67 & 0,02143 & 13,212723 \\
\hline 6 & 16008205032 & 0,67 & 0,02143 & 13,032348 \\
\hline 9 & 15816034752 & 0,67 & 0,02143 & 12,875901 \\
\hline 12 & 15647519600 & 0,67 & 0,02143 & 12,738713 \\
\hline
\end{tabular}

\section{BESI}

STAINLESS STEEL

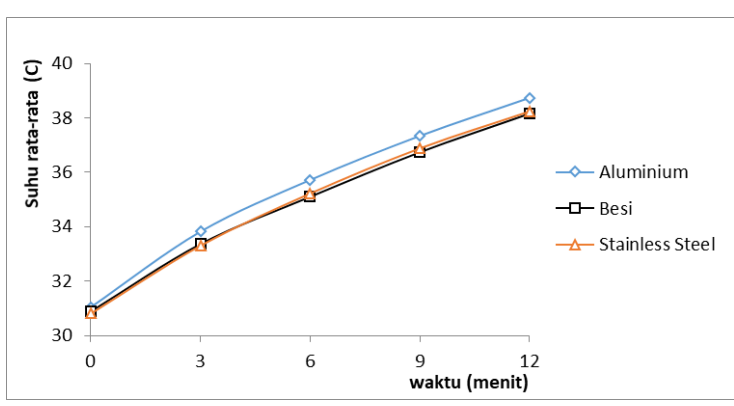

Gambar 9. Karakteristik hubungan antara waktu dan kenaikan suhu rata-rata pada jarak $5 \mathrm{~cm}$ sudut $0^{0}$ 
Grafik diatas merupakan hasil pengujian perpindahan panas secara radiasi dari ketiga bahan benda uji ( aluminium, besi dan stainless steel ) dengan variasi jarak $5 \mathrm{~cm}$. Berdasarkan grafik diatas dapat diketahui bahwa suhu ratarata dari ketiga permukaan benda uji cenderung naik secara konstan seiring dengan lamanya waktu penyerapan panas oleh benda uji hingga pada suhu tertentu mulai cenderung jenuh. Semakin lama waktu pemanasan yang diberikan oleh pemberi panas menyebabkan panas yang diterima oleh ketiga benda uji bertambah besar nilainya. Pada jarak pemanasan $5 \mathrm{~cm}$ ini aluminium memiliki kenaikan suhu berturutturut dari waktu 0 menit, 3 menit, 6 menit, 9 menit dan 12 menit sebesar $2,78^{\circ} \mathrm{C}, 1,9^{\circ} \mathrm{C}, 1,62^{\circ} \mathrm{C}$ dan $1,4^{\circ} \mathrm{C}$. Kemudian besi memiliki kenaikan suhu berturut-turut dari waktu 0 menit, 3 menit, 6 menit, 9 menit dan 12 menit sebesar $2,48^{\circ} \mathrm{C}$, $1,74^{\circ} \mathrm{C}, 1,64^{\circ} \mathrm{C}$ dan $1,42^{\circ} \mathrm{C}$. Sedangkan untuk stainless steel memiliki kenaikan suhu berturutturut dari waktu 0 menit, 3 menit, 6 menit, 9 menit dan 12 menit sebesar $2,5^{\circ} \mathrm{C}, 1,92^{\circ} \mathrm{C}, 1,66^{\circ} \mathrm{C}$ dan $1,36^{\circ} \mathrm{C}$.

Karakteristik Hubungan antara Waktu dan Laju Perpindahan Panas dengan Variasi Jarak pada Sumber Panas $125^{\circ} \mathrm{C}$ sudut $0^{\circ}$

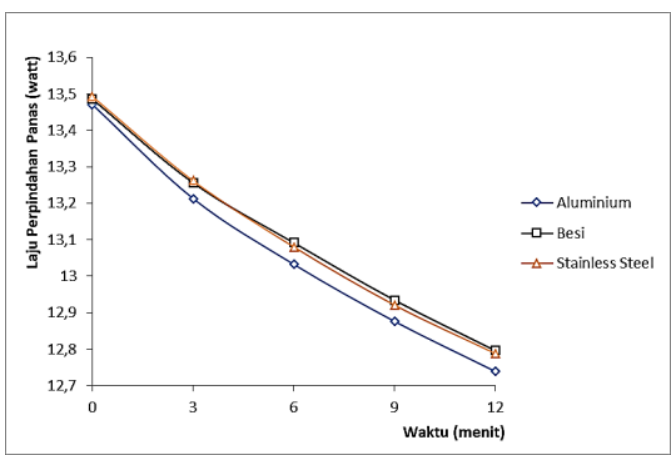

Gambar 10. Karakteristik hubungan antara waktu dan laju perpindahan panas pada jarak 5 cm sudut $0^{0}$

Grafik diatas merupakan hasil pengujian perpindahan panas secara radiasi dari ketiga bahan benda uji ( aluminium, besi dan stainless steel ) dengan variasi jarak $5 \mathrm{~cm}$. Berdasarkan grafik diatas dapat diketahui bahwa laju perpindahan panas dari ketiga permukaan benda uji cenderung turun seiring dengan lamanya waktu penyerapan panas oleh benda uji. Semakin lama waktu pemanasan yang diberikan oleh pemberi panas menyebabkan laju perpindahan panas oleh ketiga benda uji bertambah kecil nilainya. Pada jarak pemanasan $5 \mathrm{~cm}$ ini aluminium memiliki laju perpindahan panas berturut-turut dari waktu 0 menit, 3 menit, 6 menit, 9 menit dan 12 menit sebesar $13,47 \mathrm{~W}$, $13,212 \mathrm{~W}, 13,032 \mathrm{~W}, 12,875 \mathrm{~W}$ dan $12,738 \mathrm{~W}$. Kemudian besi memiliki laju perpindahan panas berturut-turut dari waktu 0 menit, 3 menit, 6 menit, 9 menit dan 12 menit sebesar $13,485 \mathrm{~W}$, $13,255 \mathrm{~W}, 13,091 \mathrm{~W}, 12,934 \mathrm{~W}$ dan $12,795 \mathrm{~W}$. Sedangkan untuk stainless steel memiliki laju perpindahan panas berturut-turut dari waktu 0 menit, 3 menit, 6 menit, 9 menit dan 12 menit sebesar 13,492 W, 13,261 W, 13,080 W, 12,920 $\mathrm{W}$ dan $12,787 \mathrm{~W}$.

\section{KESIMPULAN}

1. Spesifikasi alat uji perpindahan panas secara radiasi meliputi diameter benda uji $20 \mathrm{~cm}$, ketebalan benda uji $1 \mathrm{~mm}$, warna permukaan benda uji hitam, bahan benda uji terbuat darialuminium, besi dan stainless steel, dimensi keseluruhan alat $115 \mathrm{~cm}$ x $40 \mathrm{~cm}$ x 140 $\mathrm{cm}$, dengan penutup ruangan menggunakan kaca.

2. Nilai laju perpindahan panas terbesar didapatkan ketika pengujian pada suhu $150^{\circ} \mathrm{C}$ sudut $0^{\circ}$ pada jarak $5 \mathrm{~cm}$ sebesar 18,5457 Watt, sedangkan nilai laju perpindahan panas terendah didapatkan ketika pengujian pada suhu $125^{\circ} \mathrm{C}$ sudut $30^{\circ}$ pada jarak $25 \mathrm{~cm}$ sebesar 1,5633 Watt.

\section{DAFTAR PUSTAKA}

Holman, J. P. 2010. Heat Transfer. Tenth Edition. McGraw-Hill. USA.

Incropera, Frank P., David P. Dewitt dkk. 2002. Heat and Mass Transfer. United States of America: R.R Donnelly (Jefferson City).

Koestoer \& Raldi Artono. 2002. Perpindahan Kalor untuk Mahasiswa Teknik. Jakarta: Salemba Teknika.

Kreith, Frank. 1991. Perpindahan Panas. Alih bahasa Prijono, Arko Jakarta: PT Erlangga.

Martinez, Isidoro. 2018. Radiative View Factors. http://webserver.dmt.upm.es/ isidoro/tc3/ Radiation\%20View\%20factors.pdf . 08 Agustus 2018.

Masyithah \& Haryanto. 2006. Perpindahan Panas. Medan: Departemen Teknik Kimia, Universitas Sumatra Utara.

Pearson. 1992. Conceptual Physics tenth edition. San Fransisco: City College of San Fransisco. 
Rajawali, Putra. 2013. Makalah Aluminium.

http://putrarajawali76.blogspot.com/2013/

02/makalah-aluminium.html. 27 Juni 2018.

Setiarso, Riwan. 2015. Pengembangan Media

Pembelajaran Perpindahan Panas Radiasi dengan Variasi Spesimen Uji. Skripsi Universitas Negeri Semarang.

Yasminto, Bambang. 2012. Makalah Besi. http://bkv315a.blogspot.com/2012/08/mak alah-besi.html. 27 Juni 2018.

Yunus, Asyari D. 2010. Perpindahan Panas dan Massa. Universitas Darma Persada Jakarta. 